\title{
INVESTIGATION OF BIOSENSOR POTENTIAL COMPONENT STABILITY CAUSED BY INFLUENCE OF EXTERNAL CONDITION
}

\author{
BADANIE WPEYWU WARUNKÓW ZEWNETRZNYCH \\ NA STABILNOŚĆ POTENCJALNEGO KOMPONENTU BIOSENSORÓW
}

\begin{abstract}
The analysis of UV-VIS spectrum was used for testing changes through 36 days and the impact of external conditions (reduced temperature (R), microwave radiation (M) and normal conditions (NC) for comparisons) on the stability of: BSA and BSA-Fe ${ }^{2+}$ complexes after different treating procedure. The increase of BSA absorption with increasing concentration of $\mathrm{Fe}^{2+}$ was observed. Increased absorption of BSA, and BSA-Fe ${ }^{2+}$ with time, related probably to conformational changes present in the protein and changes in electrostatic reactions within the BSA-Fe ${ }^{2+}$ complexes. Examination of the impact of an external factor on stabilization of the protein and complexes showed a tendency to keep the stability under reduced temperature and a trend with accelerated protein and complex aging under microwave radiation. The observed tendencies to changes under the influence of external factors became more significant in time. These effects were most probably related to changes of the protein structure and time, while the observed trend of accelerating the changes was impacted by the applied external factors.
\end{abstract}

Keywords: biosensor, BSA, UV-Vis

\section{Introduction}

At the present time, environmental protection is essential due to human health and well-being. Care for the quality of water, earth and air has become very important for many reasons including protecting the ozone layer, preserving potable water and human food chain. Pollution monitoring, pathogenic detection and analysis can provide an important aid in the choice of the strategy to control the level of possibly dangerous elements. The procedures conventionally use techniques as: high-performance liquid chromatography (HPLC), fluorimetric or calorimetric immunoassay and liquid chromatography mass spectroscopy (LC-MS), electrophoresis, multispectral image processing [1], solid-phase adsorption toxin tracking (SPATT) and also very often used in medicine: flow cytometry, cytogenetic analysis genetic analysis and qualitative analysis [2]. Unfortunately, the methods do not allow an easy, rapid measurement due to complex analytical steps,

\footnotetext{
${ }^{1}$ Department of Computer Science and Automatics, Faculty of Mechanical Engineering and Computer Science, University of Bielsko-Biala, ul. Willowa 2, 43-309 Bielsko-Biała, Poland

*Corresponding author: awitkowska@ath.bielsko.pl
} 
expensive laboratory equipment, well trained personnel and in some cases increasing time of analysis. The environmental protection needs suitable analytical methods for process and quality control. Methods that are rapid, reliable, specific and cost effective in their provision of information about physical and chemical characteristics. Good proposal in this issue are biosensors and sensor network [3].

According to the definition by International Union of Pure Applied Chemistry (IUPAC), a biosensor is: a self-contained integrated device capable of proving specific quantitative analytical information using elements retained in direct spatial contact with transduction elements [4].

Biosensor structure is based on the receptor layer and transducer [5, 6]. The receptor layer is a sensitive, selective matrix, containing a biological element. On its surface (according to the lock-fit mechanism) there is an uptake of a substance called an analyte. There is a lot of biosensor type, depending on the substance placed in the uptake center, e.g. enzymatic biosensors, protein biosensors or immunosensors. Stability of receptor layer is related to the useful life of such sensor type [7].

In the transducer layer, there is a transformation of the result of the biological impact (between the molecules of receptor and analytes) into a measurable signal.

Each of biosensor types have advantages and limitations based on the intended application, and the parameters that are required for optimal performance.

The choice of biosensor design must consider factors such as the ligand specificity, sensitivity, dynamic range, functional range, mode of output, time of activation, ease of use, and ease of engineering [8].

Biosensor limitation are associated with:

- loosing activity of capture center during immobilization

- irreversible interaction (i.e. antibody-antigen)

- binding capacity (i.e. antibody) which is extremely depend on surrounding condition ( $\mathrm{pH}$, temperature)

- expensive (i.e. high cost of the source, extracting, isolating, purifying) [9]

A wide range of applications makes biosensors very attractive for economic reasons. Based on the report of Markets and Markets Company for 2017 [10], the value of the biosensor market in 11.39 billion USD and it is estimated to reach 27.06 billion USD in 2022. Therefore, the recent years show increased interest in development of such devices, both with respect to research and construction. Biosensors are extensively used in:

- environment protection [11-14] where they are a tool to detect water contaminants, harmful gases and various odorants

- food industry [15-22] where they are used to detect pesticides examination of product freshness, harmful toxins contained in food, assessment of fungal contamination in grain and detection of specific odorant molecules in nourishment

- defense industry, where they are used to detect warfare agents [22]

- in medicine, where they are extensively used for diagnostics [23-28] to detect markers in cancerous processes, concentration of sugar in blood, detect bacteria and viruses or early identification of diseases, infections and metabolic disorders [29].

Despite the extensive applications of biosensors, there are continuous attempts to improve the existing devices and develop a new generation of sensors.

Considering the latest trends in the development of biosensors, a few research directions with works in progress can be distinguished: miniaturization the existing sensors, application of graphene, multi-analyte detection, research works on wireless biosensors, the 
use of nonotechnology achievements and the latest materials in the design of biosensors enhancement of the existing sensors by improving: sensitivity, selectivity, reproducibility, accuracy. Among them, the studies on the receptor layer stability [30] could be distinguish.

Stability of receptor layer related to the activity of biosensor matrix components during biosensor use and determine the usable life of the device.

Therefore, in the present study, taking into account existing problems associated with biosensor receptor layer stability, the effect of influence external conditions (reduced temperature $(\mathrm{R})$, microwave radiation $(\mathrm{M})$ and normal conditions (NC) on BSA-Fe ${ }^{2+}$ complexes) was investigated.

Bovine Serum Albumin (BSA) is protein of 550 residues and molecular weight, $\mathrm{MW}=66 \mathrm{kDa}[30,31]$. The protein is widely used in the biosensors construction. The protein found application in amperometric enzyme-based biosensor for immobilization. Different immobilization methods for enhancement of operational stability of the immobilized enzyme electrode are use. Among tested methods of immobilization, cross-linking method with bovine serum albumin is superior to the other methods in terms of sensitivity, limit of detection, response time, and operating and thermal stability [32]. BSA is a commonly used target to analyse when designing new immunochemical assays $[33,34]$. It also states common protein standard, on surfactant-coated glass substrates embedded with indium-tin-oxide (ITO) electrodes [35]. During last decade grown of interest for use metal ions in biosensor study has been noticed [36, 37]. Metal ions are known to enhance the biological activity. Positively charged metal complexes show tremendous affinity towards the negatively charged bio-molecules like ATP, proteins, nucleic acids etc. under physiological conditions [38]. Previous research under BSA+Fe ${ }^{2+}$ complexes has proved that binding of the complex with bio-molecules may induce considerable changes in the conformation of BSA [38]. Study on the binding of chloroamphenicol (CPC) with bovine serum albumin proved that the metal ions $\mathrm{Ca}^{2+}, \mathrm{Ni}^{2+}$, $\mathrm{Mg}^{2+}, \mathrm{Fe}^{2+}$ and $\mathrm{Cu}^{2+}$ affect the binding constant between CPC and BSA [39]. In our study $\mathrm{Fe}^{2+}$ ions was considered as a factor affecting the protein.

\section{Material and methods}

BSA in a solid state (crystallized and lyophilized powder (minimum purity of 99\%)), essentially globulin free BSA (lot: SLBK3063V) and $\mathrm{Fe}^{2+}$ (sulfate heptahydrate: lot: SLBL6319V) were obtained from Sigma - Aldrich.

Using the double beam UV-VIS (Halo DB-20R) spectrophotometer by Dynamica, absorption spectra of the following water solutions were examined: $\mathrm{BSA}, \mathrm{Fe}^{2+}$ and $\mathrm{BSA}+\mathrm{Fe}^{2+}$ mixtures. The experiment covered two stages.

The first stage classified as initial was performed to determine correct concentrations of $\mathrm{Fe}^{2+}$. The absorption spectra $(190-400 \mathrm{~nm})$ were used to examine: $\operatorname{BSA}\left(2 \mathrm{mg} / \mathrm{cm}^{3}\right)+\mathrm{Fe}^{2+}\left(0.5 ; 1 ; 1.5 ; 2 ; 4 \mathrm{mg} / \mathrm{cm}^{3}\right)$. The UV-VIS spectra of $\left(\mathrm{BSA}+\mathrm{Fe}^{2+}\right)$ have been recorded for all $\mathrm{Fe}^{2+}$ concentrations.

The selected concentration of BSA $2 \mathrm{mg} / \mathrm{cm}^{3}$ was based on the earlier tests. The tests have been conducted with the use double bean UV-VIS spectrophotometer. Absorption spectra were taken for BSA in different concentration $(0.25,0.5,1,2,3,4) \mathrm{mg} / \mathrm{cm}^{3}$. The results was published by Klos-Witkowska et al. [40].

The concentration of BSA $2 \mathrm{mg} / \mathrm{cm}^{3}$ has been chosen because it seems to be optimal for our experiment. 
The second stage of the experiment involved stability testing by tracking absorption changes in time and under the influence of external factors, such as: temperature $\left(4^{\circ} \mathrm{C}\right)$, microwave radiation and for comparisons room conditions (room temperature, separation from sunlight). For stage II, only 3 ( $\mathrm{Fe}^{2+}$ concentrations) were selected for further experiments. The criterion was the readability of spectra, which was better for samples $(0.5 \mathrm{Fe}$ and $4 \mathrm{Fe})$ and sample $\left(1.5 \mathrm{mg} / \mathrm{cm}^{3}\right)$ than for $\left(1 \mathrm{Fe}^{2+}\right.$ and $\left.2 \mathrm{Fe}^{2+}\right)$. Therefore, finally, it was decided to use concentrations of $\mathrm{Fe}^{2+}$ such as $\left(0.5: 1.5 ; 4 \mathrm{mg} / \mathrm{cm}^{3}\right)$. Considering the results of the first stage, the following concentrations were selected: $\mathrm{BSA}\left(2 \mathrm{mg} / \mathrm{cm}^{3}\right)+\mathrm{Fe}^{2+}\left(0.5 \mathrm{mg} / \mathrm{cm}^{3}\right), \operatorname{BSA}\left(2 \mathrm{mg} / \mathrm{cm}^{3}\right)+\mathrm{Fe}^{2+}\left(1.5 \mathrm{mg} / \mathrm{cm}^{3}\right)$, $\mathrm{BSA}\left(2 \mathrm{mg} / \mathrm{cm}^{3}\right)+\mathrm{Fe}^{2+}\left(4 \mathrm{mg} / \mathrm{cm}^{3}\right)$. The UV-VIS were examined for the range of 220-350 nm, to observe changes occurring in the peak of approx. $280 \mathrm{~nm}$ resulting from the aromatic residues such as tryptophan (Trp), tyrosine (Tyr) and phenylalanine (Phe) present in the protein [25]. An additional experiment was made to verify the stability of $\mathrm{Fe}^{2+}$ at different concentrations: $\mathrm{Fe}^{2+}\left(0.5: 1.5: 4 \mathrm{mg} / \mathrm{cm}^{3}\right)$ in time, for samples kept in room conditions. For water solutions of $\mathrm{Fe}^{2+}$, absorption spectra were gathered within 190-1100 nm. Examinations of the second stage were performed at seven-day intervals: On days: $1,8,15,22,29,36$. In the first day of the second-stage experiment, $\operatorname{BSA}\left(2 \mathrm{mg} / \mathrm{cm}^{3}\right)+\mathrm{Fe}^{2+}(0.5 ; 1.5 ; 4)$ solutions were prepared. Absorption spectra were measured at 220-350 nm. Next, the solutions were split into 3 groups: The first group included solutions kept in normal conditions, in a shaded place, marked as (NC).

The second group was made by solutions kept in reduced temperature $\left(4{ }^{\circ} \mathrm{C}\right)(\mathrm{R})$, and the third group included solutions exposed to microwave radiation and placed in the $4{ }^{\circ} \mathrm{C}$ after 30 minutes. Group 3 was marked as (M).

The experiments were made in three test batches (S1, S2, S3) in order to exclude accidental results. In further analysing, average absorption, standard deviation and aligned trend lines (with an exponential function) were calculated based on the results for three batches

\section{Results and discussion}

Figure 1 presents UV-VIS spectra for pure BSA $\left(2 \mathrm{mg} / \mathrm{cm}^{3}\right)$ and BSA complexes $\left(2 \mathrm{mg} / \mathrm{cm}^{3}\right)+\mathrm{Fe}^{2+}\left(0.5 ; 1 ; 1.5 ; 2 ; 4 \mathrm{mg} / \mathrm{cm}^{3}\right)$ in the first day sample. UV-visible absorption measurement is a very simple method and applicable to explore the structural change and formation of a complex.

The 250-310 $\mathrm{nm}$ spectrum shows a $277 \mathrm{~nm}$ peak that results from aromatic amino acid residues such as tryptophan (Trp), tyrosine (Tyr) and phenylalanine (Phe) present in the protein. Increased absorption of the sample at increasing $\mathrm{Fe}^{2+}$ concentration can be seen. This effect is related to changing sizes of the particle as $\mathrm{Fe}^{2+}$ ions are added and complex formation. A similar mechanism was described by Huang et al for $\mathrm{Cu}^{2+}$ ions [34] and by Zhang et al [39] for chloroamphenicol (CPC)

Figure 2 presents UV-VIS spectra for pure $\mathrm{BSA}, \mathrm{Fe}^{2+}$ and $\mathrm{BSA}-\mathrm{Fe}^{2+}$ complex in the 190-350 nm wavelength range. The pure BSA spectrum a) shows an absorption peak at $277 \mathrm{~nm}$, which has been assigned to the $\pi-\pi^{*}$ transition of aromatic amino acid residues (Trp, Tyr and Phe). The c) curve of the BSA-Fe ${ }^{2+}$ complex shows a non-obvious shift of the $277 \mathrm{~nm}$ absorption peak and significant enhancement of absorption before $280 \mathrm{~nm}$, which is related to multiple binding sites for $\mathrm{Fe}^{+2}$ including $-\mathrm{NH}, \mathrm{COOH},-\mathrm{SH},-\mathrm{OH}$ groups present in the protein. The complex formation is associated with interaction forces between small 
molecules and biomolecules. The forces may include electrostatic interactions, van der Waals interactions, multiple hydrogen bonds and hydrophobic interaction. The b) curve presents broad absorbance within 190-260 $\mathrm{nm}$ for $\mathrm{Fe}^{2+}$ dissolved in water. This phenomenon is related to overlapping of absorption bands resulting from different energies of nanocrystals having disparate sizes. The change in absorption intensity is correlated to the particle size of the examined substance.

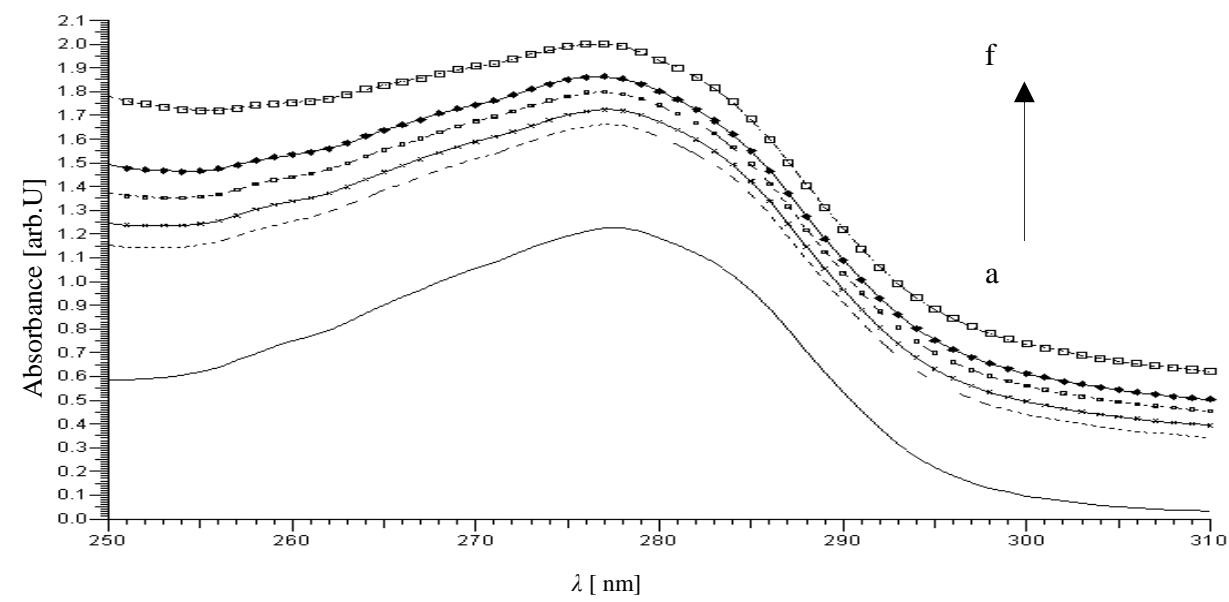

Fig. 1. UV-VIS spectra for: a - pure BSA $\left(2 \mathrm{mg} / \mathrm{cm}^{3}\right)$ and BSA complexes in the first day sample; b - $\operatorname{BSA}\left(2 \mathrm{mg} / \mathrm{cm}^{3}\right)+\mathrm{Fe}^{2+}\left(0.5 \mathrm{mg} / \mathrm{cm}^{3}\right) ; \quad \mathrm{c}-\operatorname{BSA}\left(2 \mathrm{mg} / \mathrm{cm}^{3}\right)+\mathrm{Fe}^{2+}\left(1 \mathrm{mg} / \mathrm{cm}^{3}\right)$; $\mathrm{d} \quad-\operatorname{BSA}\left(2 \mathrm{mg} / \mathrm{cm}^{3}\right)+\mathrm{Fe}^{2+}\left(1.5 \mathrm{mg} / \mathrm{cm}^{3}\right) ;$ e - $\operatorname{BSA}\left(2 \mathrm{mg} / \mathrm{cm}^{3}\right)+\mathrm{Fe}^{2+}\left(2 \mathrm{mg} / \mathrm{cm}^{3}\right)$; f - BSA $\left(2 \mathrm{mg} / \mathrm{cm}^{3}\right)+\mathrm{Fe}^{2+}\left(4 \mathrm{mg} / \mathrm{cm}^{3}\right)$

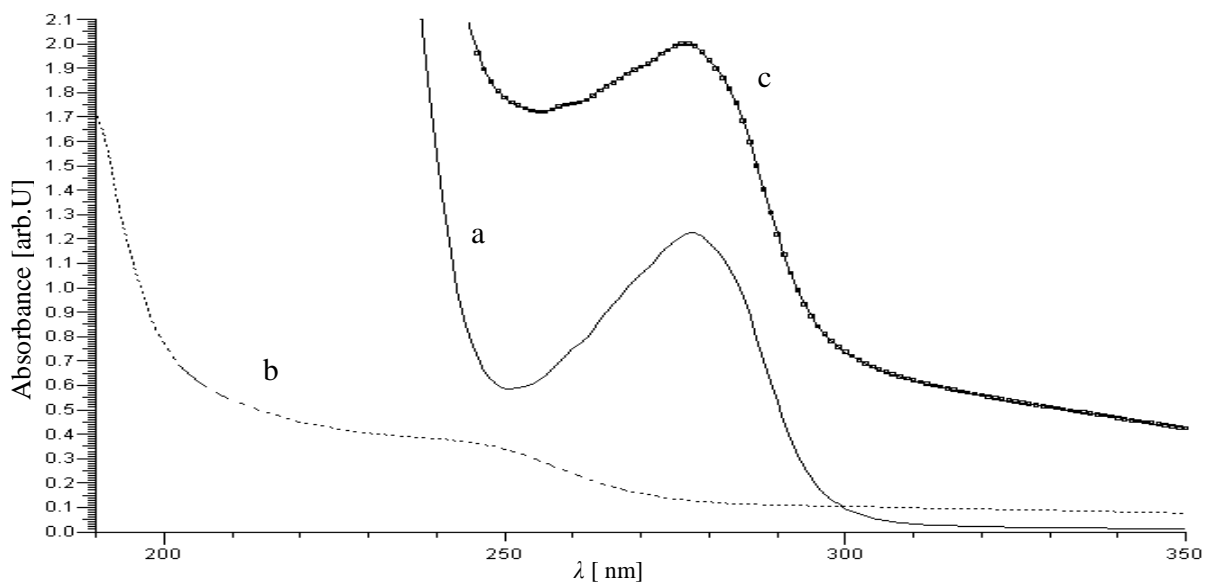

Fig. 2. UV-VIS spectra of: a - BSA $\left(2 \mathrm{mg} / \mathrm{cm}^{3}\right), \mathrm{b}-\mathrm{Fe}^{2+}\left(4 \mathrm{mg} / \mathrm{cm}^{3}\right), \mathrm{c}-\mathrm{BSA}\left(2 \mathrm{mg} / \mathrm{cm}^{3}\right)+\mathrm{Fe}^{2+}\left(4 \mathrm{mg} / \mathrm{cm}^{3}\right)$

In the further phase of the experiment, the impact of external factors on BSA and BSA-Fe complexes was examined to address the question of whether application of 
external factors on the component of the receptor layer being BSA and the analyte cross-linked within the matrix can extend matrix stability.

Taking into account earlier tests related to time changes both for BSA and BSA-Fe ${ }^{2+}$ complexes, it can be seen that absorption increases with time (Fig. 3), i.e. stability of the sample is reduced. This effect is most probably related to the BSA conformational changes and changing force of electrostatic interactions in the BSA-Fe ${ }^{2+}$ complex. Also the slow $\mathrm{Fe}(\mathrm{II})$ oxidation to $\mathrm{Fe}(\mathrm{III})$ might occurred. This is of particular importance in the long term experiment of "BSA stability" (36 days) - Figure 3, Table 1.

a)

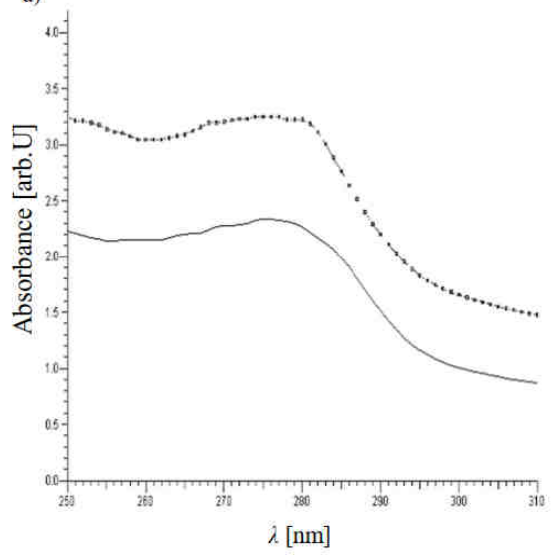

b)

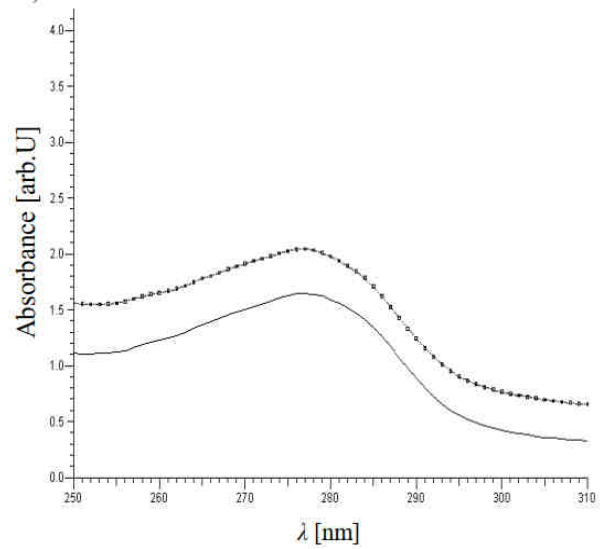

Fig. 3. UV-VIS spectra showing changes occurring in time (on the $8^{\text {th }}$ day - dotted line and on the $1^{\text {st }}$ day straight line) for complexes with different concentrations of $\mathrm{Fe}^{2+}$ ions kept in the $4{ }^{\circ} \mathrm{C}$; a) $\operatorname{BSA}\left(2 \mathrm{mg} / \mathrm{cm}^{3}\right)+\mathrm{Fe}^{2+}\left(4 \mathrm{mg} / \mathrm{cm}^{3}\right)$, b) $\operatorname{BSA}\left(2 \mathrm{mg} / \mathrm{cm}^{3}\right)+\mathrm{Fe}^{2+}\left(0.5 \mathrm{mg} / \mathrm{cm}^{3}\right)$

Comparison the surface area under the curve on the $1^{\text {st }}$ day and $8^{\text {th }}, 15^{\text {th }}, 22^{\text {th }}, 29^{\text {th }}, 36^{\text {th }}$ day

Table 1

\begin{tabular}{|c|c|c|c|c|c|}
\hline Sample & \multicolumn{5}{|c|}{ Relative increase in area under the curve [\%] } \\
\hline & $\mathbf{8}^{\text {th }}$ day & $\mathbf{1 5}^{\text {th }}$ day & $\mathbf{2 2}^{\text {nd }}$ day & $\mathbf{2 9}^{\text {th }}$ day & $\mathbf{3 6}^{\text {th }}$ day \\
\hline $\mathrm{BSA}\left(2 \mathrm{mg} / \mathrm{cm}^{3}\right)+\mathrm{Fe}^{2+}\left(0.5 \mathrm{mg} / \mathrm{cm}^{3}\right)$ & 42 & 47 & 58 & 65 & 71 \\
\hline $\mathrm{BSA}\left(2 \mathrm{mg} / \mathrm{cm}^{3}\right)+\mathrm{Fe}^{2+}\left(1.5 \mathrm{mg} / \mathrm{cm}^{3}\right)$ & 50 & 62 & 72 & 87 & 92 \\
\hline $\mathrm{BSA}\left(2 \mathrm{mg} / \mathrm{cm}^{3}\right)+\mathrm{Fe}^{2+}\left(4 \mathrm{mg} / \mathrm{cm}^{3}\right)$ & 62 & 74 & 85 & 92 & 96 \\
\hline
\end{tabular}

Fragmentation and aggregation of investigated protein might occur with time. Distance in the polypeptide chain could be changed, and it results in a strength change. Over time, denaturation of protein is occur. During this process, a 3-fold structure of the protein is disrupted, resulting in loss of biological activity of the protein.

Conformational changes of BSA were labeled as follows: E - expanded, F - fast-highly changed state, $\mathrm{N}$ - normal, $55 \%$ - helix structure, B - basic and A - aged unfolded state. The N-F conformational transition is characterized by a sudden opening of the molecule. The process is very violent and it means $100 \mathrm{~ms}$ and concerns the spreading of the third domain. $\mathrm{F}$ form is characterized by much lower solubility and decreased helix structure. $\mathrm{E}$ form is a form of stretched protein, which decomposes into a helix I domain that is joined to the helix II domain. Another known conformation is the conformation B from which the next isomerization progresses to the ageing forms A [4]. 
During the denaturation process electrostatic interaction could be changed. Electrostatic interactions play an important role in stabilizing the spatial structure of macromolecules. Taking into account the range of this impact, short-range $(<5 \AA ; 1 \AA$ (angstrom) $=0.1 \mathrm{~nm})$ and far-range $(>5 \AA)$ are distinguished. Long-range electrostatic interactions include ion-ion type interactions (salt bridge) or dipol-ion. These interactions belong to relatively strong interactions, the strength is from $40-400 \mathrm{~kJ} / \mathrm{mol}[41]$.

The effects of the close range are also called van der Waals interactions. These interactions are weaker than the long-range interactions. Examples of short-range interactions in the protein molecule are both mutual attraction forces and mutual repulsive forces.

Due to the fact that the tests are carried out in aqueous solutions, the hydrophobic interaction are also very important for the conformation of the tested protein.

Hydrophobic interactions occur between amino acid residues containing the aromatic system, among (Phe, Tyr, Trp).

It also was found that the exposition to microwave radiation caused sample destabilization to accelerate. This effect was obtained for complexes in all $\mathrm{Fe}^{2+}$ concentrations. As time passed, samples that were kept in a dark place in normal conditions were also destabilized, however, the aging process was slower here than in the case with radiation exposure. The performed experiment shows that presence of $\mathrm{Fe}^{2+}$ ions also impacts the changes of BSA conformation occurring in time and the stability of sample.

Figure 3 presents changes occurring in time (on the $8^{\text {th }}$ day and on the $1^{\text {st }}$ day) for complexes with different concentrations of $\mathrm{Fe}^{2+}$ ions.

The gathered UV-VIS spectra in the range of 250-310 nm wavelength show the increase in complex absorption in time. It could be connected to fact that binding constant slightly decreased with time and the complex was partly decomposed. Similar effect was observe for BSA-chromate complex at higher temperature [42]. Kboudin et al. [43] observed the interaction of novel aminophosphinic acids with BSA. They found that polarity around the Trp residues increased and the hydrophobicity decreased. Change of the hydrophobic microenvironment caused the changes of BSA conformation [44]. In our study similar effect concerning $\mathrm{BSA}+\mathrm{Fe}^{2+}$ complexes have been found. The increase in complex absorption in time is faster for samples with higher concentration of $\mathrm{Fe}^{2+}$ ions. Analysis base on area under curve calculation has been use to showing changes in absorption over time depending on $\mathrm{Fe}^{2+}$ concentration. Area under curve method involves the calculation of integrated value of absorbance with respect to the wavelength between two selected wavelengths such as $\lambda 1$ and $\lambda 2[45,46]$. The area under curve between $\lambda 1$ and $\lambda 2$ were calculated by UV Solution 2.2 software. Comparison of the surface area under the curve on the $1^{\text {st }}$ day is presented in Table 1 . It also conform, that increase in absorbance is faster for samples with higher concentration of $\mathrm{Fe}^{2+}$ ions. The same trend has been obtained for other time intervals.

The intensity of absorption peaks both for complexes of BSA and pure BSA increases in time.

Considering the impact of external conditions (reduce temperature and microwave radiation) on the stability of both $\operatorname{BSA}\left(2 \mathrm{mg} / \mathrm{cm}^{3}\right)$ and complexes of $\mathrm{BSA}\left(2 \mathrm{mg} / \mathrm{cm}^{3}\right)+\mathrm{Fe}^{2+}\left(0.5 ; 1.5 ; 4 \mathrm{mg} / \mathrm{cm}^{3}\right)$.

The analysis of impact of the reduced temperature and room conditions on the stability of $\operatorname{BSA}\left(2 \mathrm{mg} / \mathrm{cm}^{3}\right)$ and complexes of $\operatorname{BSA}\left(2 \mathrm{mg} / \mathrm{cm}^{3}\right)+\mathrm{Fe}^{2+}\left(0.5 ; 1.5 ; 4 \mathrm{mg} / \mathrm{cm}^{3}\right)$ in time 
were performed. Analysis was based on alternations of peak intensity. Figure 4 presents the characteristics of obtained changes for $\mathrm{BSA}\left(2 \mathrm{mg} / \mathrm{cm}^{3}\right)+\mathrm{Fe}^{2+}\left(0.5 \mathrm{mg} / \mathrm{cm}^{3}\right) \mathrm{kept}$ in $4{ }^{\circ} \mathrm{C}$ and room conditions for 36 days.

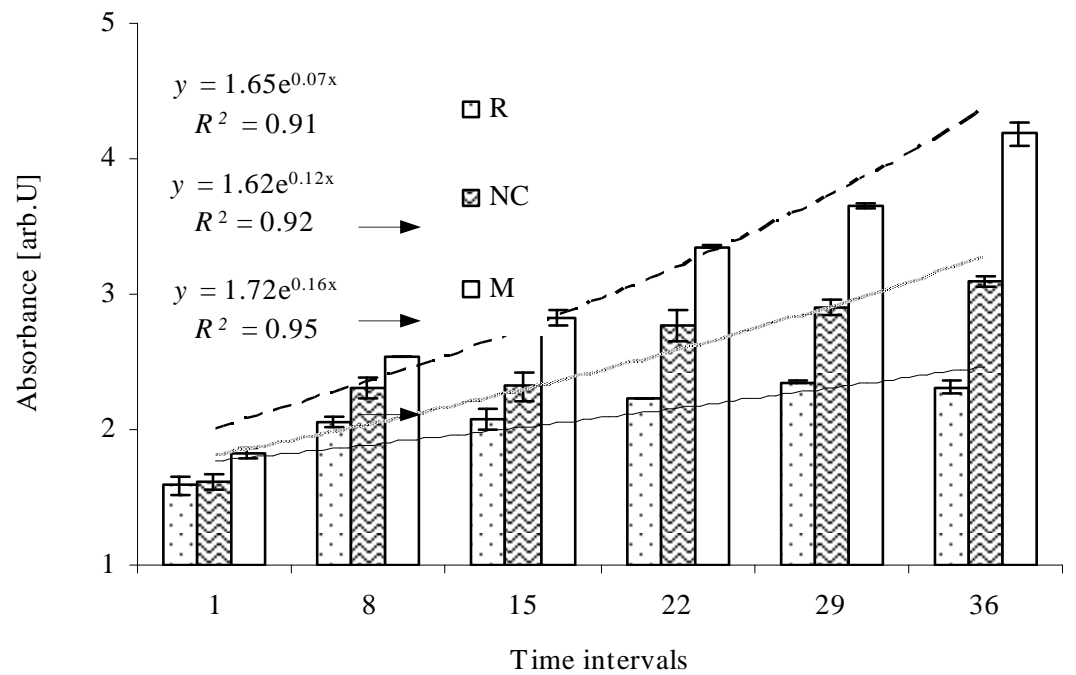

Fig. 4. Changes in absorption of $\operatorname{BSA}\left(2 \mathrm{mg} / \mathrm{cm}^{3}\right)+\mathrm{Fe}^{2+}\left(0.5 \mathrm{mg} / \mathrm{cm}^{3}\right)$ vs. time for samples kept in $4{ }^{\circ} \mathrm{C}$ $(\mathrm{R})$, normal conditions (NC) and microwave irradiated for 36 days (M)

The presented diagram shows the increase in absorption intensity in time, which is much more intensified for complexes after microwave exposition and samples kept in the normal conditions than in $4{ }^{\circ} \mathrm{C}$. This effect is most probably related to BSA conformational changes occurring faster after radiation and in normal conditions than under reduced temperature. A trend with sample stabilization at reduced temperature can be noticed. A similar nature of changes was observed for pure $\mathrm{BSA}\left(2 \mathrm{mg} / \mathrm{cm}^{3}\right)$ and complexes of $\mathrm{BSA}+\mathrm{Fe}^{2+}\left(1.5 ; 4 \mathrm{mg} / \mathrm{cm}^{3}\right)$.

Fitting the obtained curves with the

$$
y=\mathrm{e}^{a x}
$$

the $a$ parameter as the factor standing for change dynamics, it can be said that this parameter was higher for irradiated solution and samples kept in normal conditions than for samples kept in $4{ }^{\circ} \mathrm{C}$.

Hence, it can be concluded that the reduced temperature has a more beneficial influence on the stability of samples than normal conditions and radiation.

The analysis of influence of microwave radiation shows trend to accelerate aging of $\mathrm{BSA}$ and $\mathrm{BSA}+\mathrm{Fe}^{2+}$ complexes. Under microwave radiation two type of protein damage might be happen: fragmentation and aggregation. The irradiation could cause break down of the polypeptide chain resulting in the formation of low molecular weight molecules. Also exposition of BSA solution on microwave radiation could result in disruption of ordered structure, degradation, aggregation of polypeptide chains because of oxygen radicals generated in water radiolysis [47, 48] similar effect has been observed under $\gamma$ radiation. Generally, radiation causes irreversible changes at the molecular level by the 
breakage of the covalent bonds of polypeptide chains. Exposure of proteins to oxygen radicals results in non-random and random fragmentations. The protein fragmentation in aqueous solutions was affected by the local conformation of a particular amino acid in the protein, its accessibility to water radiolysis products, and the primary amino acid sequence [49]. Considering the dependency on concentration, more dynamic changes were observed for the complexes of $\operatorname{BSA}\left(2 \mathrm{mg} / \mathrm{cm}^{3}\right)+\mathrm{Fe}^{2+}\left(1.5 ; 4 \mathrm{mg} / \mathrm{cm}^{3}\right)$ than for $\mathrm{BSA}\left(2 \mathrm{mg} / \mathrm{cm}^{3}\right)+\mathrm{Fe}^{2+}\left(0.5 \mathrm{mg} / \mathrm{cm}^{3}\right)$. Therefore, it can be concluded that the presence of $\mathrm{Fe}^{2+}$ ions impacts the stability of the protein as well. The higher the concentration of ions, the worse stability of samples.

\section{Conclusions}

To recapitulate, the performed tests showed: an increase in $\operatorname{BSA}\left(2 \mathrm{mg} / \mathrm{cm}^{3}\right)+\mathrm{Fe}^{2+}$ absorption with increasing concentration of $\mathrm{Fe}^{2+}$. This effect is related to changing sizes of the particle as $\mathrm{Fe}^{2+}$ ions are added. Similar effect has been described by Huang et al. for $\mathrm{Cu}^{2+}$ ions [34] and by Zhang et al. [39] for chloroamphenicol (CPC).

Examination of the impact of an external factor on stabilization of the protein and complexes of $\mathrm{BSA}\left(2 \mathrm{mg} / \mathrm{cm}^{3}\right)+\mathrm{Fe}^{2+}\left(0.5 ; 1.5 ; 4 \mathrm{mg} / \mathrm{cm}^{3}\right)$ showed a tendency to retain the stability under reduced temperature and a trend to accelerate protein and complex aging under microwave radiation.

Relating the obtained results to tests with biosensors allows us to conclude that external conditions impact the stability of BSA and the concentration of examined substances is also important for the stability of a biosensor.

\section{References}

[1] Petruk V, Kvaternyuk S, Yasynska V, Kozachuk A, Kotyra A, Romaniuk R, et al. The method of multispectral image processing of phytoplankton processing for environmental control of water pollution. Proc SPIE - Int Soc Optical Eng. Vol 9816, 2015, Article number 98161N. DOI: 10.1117/12.2229202.

[2] Martsenyuk, V, Warwas K, Augustynek K, Klos-Witkowska A, Karpinskyi V, Klymuk N, et al. ICCAS 2016: $16^{\text {th }}$ IntConf Control, Automation and Systems. Korea. 2016:489-94. DOI: 10.1109/ICCAS.2016.7832365.

[3] Bernaś M, Płaczek B. Int J Distributed Sensor Networks. 2015;403242. DOI: 10.1155/2015/403242.

[4] Thevenot D, Toth K, Dust R, Wilson G. Pure Appl Chem. 1999; 2333-48. DOI: 10.1351/pac199971122333.

[5] Kłos-Witkowska A. Acta Phys Polon. 2018;133(1):101-4. DOI: 10.12693/APhysPolA.133.101.

[6] Fabisiak K, Kowalska M, Szybowicz M, Paprocki K, Popielarski P, Wrzyszczyński A, et al. Adv Eng Mat. 2013;15(10):935-40. DOI: 10.1002/adem.201200351.

[7] Martsenyuk V, Kłos-Witkowska A, Sverstiuk A. Electronic J Qualitative Theory Differential Equations. 2018;27:1-31. DOI: 10.14232/ejqtde.2018.1.27.

[8] Carpenter A, Paulsen I, Williams T. Genes. 2018;9:375. DOI: 10.3390/genes9080375.

[9] Rajpoot K. Biosensors J. 2017;6:145. DOI: 10.4172/2090-4967.1000145.

[10] Markets and Markets Company. Available from: https://www.marketsandmarkets.com/MarketReports/biosensors-market-798.html?gclid=CjwKCAiAiarfBRASEiwAw1tYv37aDB7up3sF3bRDT3ovYqEBrGB8Fwv8RoMwFsPe_x22cRaGvcgPhoCzvAQAvD_BwE.

[11] Kłos-Witkowska A. Polish J Environ Stud. 2015;1:19-25. DOI: 10.15244/pjoes/28352.

[12] Nowotny V, Barek J. Ecol. Chem Eng S. 2017;24(2):277-84. DOI: 10.1515/eces-2017-0019.

[13] Ron E. Curr Opin Biotechnol. 2007;18:252-6. DOI: 10.1016/j.copbio.2007.05.005.

[14] Kochana J, Adamski J, Parczewski A. Ecol. Chem Eng S. 2012;19(3):383-91. DOI: 10.2478/v10216-011-0028-5.

[15] Verma N, Bhardwaj A. Appl Biochem Biotechnol. 2015;175:3093-119. DOI: 10.1007/s12010-015-1489-2.

[16] Neethirajan S , Ragavan V, Weng X, Chand R. Biosensors. 2018;8:23. DOI: 10.3390/bios8010023.

[17] Adler C. Foods. 2014;3:491-510. DOI: 10.3390/foods3030491. 
[18] Bunney J, Williamson S, Atkin D, Jeanneret M, Cozzolino D, Chapman J, et al. Current Res Nutrition Food Sci. 2017;5:183-95. DOI: 10.12944/CRNFSJ.5.3.02.

[19] Naik K, Srinivas D, Sasi B, Jakeer Basha S. Int J Pure App Biosci. 2017;5:1219-27. DOI: 10.18782/2320-7051.5546.

[20] Ahna J, Lima J, Parkb J, Ohc E, Sonc M, Hongb S, et al. Sensors Actuators B. 2015;210:9-16. DOI: 10.1016/j.snb.2014.12.060.

[21] Pietrantonio FM, Cannatà DE, Palla-Papavlu A, Fernández-Pradas J, Serra P, Varriale A, et al. Biosens Bioelectron. 2015;67:516-23: DOI: 10.1016/j.bios.2014.09.027.

[22] Burnworth M, Rowan S, Weder Ch. Chem Eur J. 2007;13:7828-36. DOI: 10.1002/chem.200700720.

[23] Kłos-Witkowska A. Acta Biochim Polon. 2016;63:215-21. DOI: 10.18388/abp.2015_1231.

[24] Sirivisoot S, Webster TJ. J Biosens Bioelectron. 2012;3:104. DOI: 10.4172/2155-6210.1000 104.

[25] Alvau M, Tartaggia S, Meneghello A, Casetta B, Calia G, Serra P, et al. Anal Chem. 2018;90:6012-9. DOI: 10.1021/acs.analchem.7b04357.

[26] Gruhl F, Rapp BE, Länge K. Adv Biochem Eng Biotechnol. 2013;133:115-48. DOI: 10.1007/10_2011_130.

[27] Luka G, Samiei E, Dehghani S, Johnson T, Najjaran H, Hoorfar M. Sensors. 2019;19(2):258. DOI: $10.3390 / \mathrm{s} 19020258$.

[28] Hu J, Wang S, Wang L, Li F, Pingguan-Murphy B, Lu T, et al. Biosens Bioelectron. 2014;54:585-97. DOI: 10.1016/j.bios.2013.10.075.

[29] Wasilewski T, Gębicki J, Kamysz W. Biosens Bioelectron. 2017;87:480-94. DOI: 10.1016/j.bios.2016.08.080.

[30] Hernández-Cancel G, Suazo-Dávila D, Medina-Guzmán J, Rosado-González M, Díaz-Vázquez L, Griebenow K. Analytica Chim Acta. 2015;854:129-39. DOI: 10.1016/j.aca.2014.11.008.

[31] Michnik A, Kłos A, Drzazga Z. J Thermal Analysis Calorimetry. 2003;77:269-77. DOI: 10.1023/B:JTAN.0000033212.93809.e1.

[32] Sarika C, Rekha K, Narasimha B, Narasimha Murthy B. 3 Biotech. 2015;5:911-24. DOI: 10.1007/s13205- 015-0292-7.

[33] Ertürk G, Berillo D, Hedström M, Mattiasson B. Biotechnol Rep (Amst). 2015;3:65-72. DOI: 10.1016/j.btre.2014.06.006.

[34] Huang P, Li Z, Hu H, Cui D. J Nanomaterials. 2010:641545. DOI: 10.1155/2010/641545.

[35] Lin CH, Lee MJ, Lee W. Appl Phys Lett. 2016;109:093703. DOI: 10.1063/1.4962169.

[36] De Acha N, Elosúa C, Corres J, Arregui F. Sensors. 2019;19(3):599. DOI: 10.3390/s19030599.

[37] Zhou Y, Haiku Z, Fang Y, Yao C. Spectrochim Acta Part A: Molecular Biomolecular Spectrosc. 2013;106:197-202. DOI : 10.1016/j.saa.2012.12.092.

[38] Rudra S, Dasmandal S, Patra C, Kundu A, Mahapatra A. Spectrochim Acta Part A: Molecular Biomolecular Spectrosc. 2016;166:84-94. DOI: 10.1016/j.saa.2016.04.050.

[39] Zhang J, Chen L, Zeng B, Kang Q, Dai L. Spectrochim Acta Part A: Molecular Biomolecular Spectrosc. 2013;105:74-9. DOI : 10.1016/j.saa.2012.11.064.

[40] Kłos-Witkowska A, Akhmetov B, Zhumangalieva N, Karpinskyi V, Gancarczyk T. ICCAS 2016: $16^{\text {th }}$ Int Conf Control, Automation Systems. Korea. 2016:976-80. DOI: 10.1109/ICCAS.2016.7832427.

[41] Sochacka J, Pacholczyk, Wójcik P. Trendy i rozwiązania technologiczne - odpowiedź na potrzeby współczesnego społeczeństwa. [Trends and technological solutions - a response to the needs of modern society] Tom 1 (81-101). Lublin: Wyd Naukowe TYGIEL; 2017. ISBN: 9788365598585.

[42] Cao H, Yi Y. Biometals. 2017;30:529-39. DOI: 10.1007/s10534-017-00222-1.

[43] Kaboudin B, Moradi K, Faghihi M, Mohammadi F. J Lumin. 2013;139:104-12. DOI: 10.1016/j.jlumin.2013.01.028.

[44] Tserkezidou C, Hatzidimitriou A, Psomas G. Polyhedron. 2016;117:184-92. DOI: 10.1016/j.poly.2016.05.044.

[45] Charan M, Suta M. Int J Pharmaceutical Sci Res. 2016;27:3781-86. DOI: 10.13040/IJPSR.0975-8232.7(9).3781-86.

[46] Attia K, Elabasawy N, Abolmagd E. Future J Pharmaceutical Sci. 2017;3:163-7. DOI. 10.1016/j.fjps.2017.06.001.

[47] Michnik A, Michalik K, Drzazga Z. J Photochem Photobiol B: Biology. 2008;90:170-8. DOI: 10.1016/j.jphotobiol.2007.12.007.

[48] Gaber M. J Biosci Bioeng. 2005;100:203-6. DOI: 10.1263/jbb.100.203.

[49] Damm M, Nusshold C, Cantillo D, Rechberger G, Sattler W, Kappe O. J Proteomics. 2012;75:5533-43. DOI: 10.1016/j.jprot.2012.07.043. 